\title{
Articles
}

Marta M. Bojko ${ }^{1}$, Marzena Feldy ${ }^{2}$, Barbara Kowalczyk ${ }^{3}$, Anna Knapińska ${ }^{4}$

\section{POLISH BUSINESS MODELS OF TECHNOLOGY TRANSFER CENTRES AGAINST FOREIGN LEADERS. CONCLUSIONS OF THE CASE STUDIES}

The authors analyse business models existing in leading technology transfer academic centres throughout the world, in order to find out to what extent they are implemented by entities in Poland. Their attention is focused on such components of business models as: legal form and methods of financing, the mission of operations, the work integration and the mechanisms of collaboration with the science and commercial sector. The study is qualitative, based on the analysis of the case studies of foreign entities. The diversity of global solutions enables a critical look at the activities of Polish technology transfer centres and points to the choice of models which are best suited to their domestic conditions. According to the authors, the improved effectiveness of technology transfer centres is an important part of the debate on the transformation of traditional universities into entrepreneurial universities.

JEL Classification Codes: 032, 034.

Keywords: Entrepreneurial university, technology transfer, business models.

\section{Introduction}

Science is a unique sphere of public activity; the diffusion of knowledge enables the building of a strong economy and the fulfilment of social ob-

\footnotetext{
${ }^{1}$ Research Fellow, Ph.D. candidate, National Information Processing Institute, Warsaw, Poland.

${ }^{2}$ Assistant Professor, Ph.D., National Information Processing Institute, Warsaw, Poland.

${ }^{3}$ Research Fellow, Ph.D., National Information Processing Institute, Warsaw, Poland.

${ }^{4}$ Research Fellow, Ph.D. candidate, National Information Processing Institute, Warsaw, Poland.
} 
jectives. Currently, however, academic institutions are treated in the same way as all other public sector organizations which have to compete for public funding (Kwiek, 2015). It is assumed that higher education institutions should actively participate in the creation of an innovative economy. In addition to research and educational activities, characteristic of the traditional Humboldtian university, the so-called third mission is gaining in importance (Etzkowitz \& Leydesdorff, 1995). A specific feature of entrepreneurial universities is the strong links with the social and economic environment.

Despite this, the university is still a space in which the social and cultural structure differs from that of commercial entities. The key role in the "selfregulating structure of the certification of knowledge" (Niedzielski \& Łobacz, 2012 , p. 13) is played by the researcher. It is with the researcher or a team of researchers generating results that the commercialization of research outcomes starts. Achieving the objectives relating to innovation has to be facilitated by the creation of specialized entities involved in the commercialization of research results and knowledge transfer to the socio-economic development by modern scientific institutions. The most popular of these are the academic centres of knowledge and technology transfer (hereinafter referred to as technology transfer centres, TTC), managing and commercialising the knowledge generated in scientific entities (Landry, Amara, Cloutier, \& Halilem, 2013).

A breakthrough on a global scale was the adoption by the US Congress in 1980 of the so-called Bayh-Dole Act. The new law gave universities the right to patent and license inventions resulting from research financed from public funds; previously, patents had been owned by the Department of Treasury and therefore did not bring any benefits to scientific institutions. Over time, solutions similar to the Bayh-Dole Act were adopted in countries such as: Argentina, Estonia, France, Germany, India, Malaysia, South Africa, and the United Kingdom. They also apply in Poland (Zuniga, 2011; Krzewiński, Budasz, Krzewińska, Gabriel, \& Sypniewska, 2014). The Bayh-Dole Act and its foreign counterparts have led not only to an increase in the number of patents, but also to the widespread creation of technology transfer centres (Mowery, Nelson, Sampat, \& Ziedonis, 2015)

The substantial increase in the number of TTCs and their evolution, aiming at developing the most effective practices for technology transfer, has 
resulted in variety of business models ${ }^{5}$ of these entities (Axanova, 2012; Landry et al., 2013). Moreover, the differentiation is increasing along with the pressure to optimise the structures that will meet the needs and expectations of the academia and the business environment (Axanova, 2012). At the same time, in spite of continuous improvement, a few of the American and European universities have been successful both in terms of the number of commercialized technologies, and achieving income from them (Conti \& Gaule, 2011; Baglieri, Baldi, \& Tucci, 2015). Business models used by universities that successfully commercialise inventions are the subject of research and serve as a role model for younger and less experienced centres.

In Poland, the first transfer centres were created in the 1990s, but interest in them increased after 2005 with the introduction of the statutory provisions relating to their activities within the structures of universities. In practice, the number of TTCs increased significantly after 2010, when a possibility opened to finance their operations from the Structural Funds. The experiences of Polish TTCs are therefore not significant, as compared to their foreign counterparts, and their business models are just starting the adaptation process to the realities of science and economy. According to Bąkowski (2015), some changes are already visible: the professionalization of services is taking place along with greater focus on the tasks related to technology transfer. Despite this, the overall balance of the activities of domestic TTCs is still not positive. On an annual basis, only a few dozen technologies are implemented in Poland, and most of them are carried out by three centres (out of the existing 42): at the AGH University of Science and Technology, the Jagiellonian University and the Technical University of Wroclaw.

Taking the unsatisfactory assessment of the activities of technology transfer centres in Poland as a starting point, the authors of the article set themselves the goal of describing the business models existing in the leading centres in the world. Due to the fact that the Polish TTCs follow the path defined by global leaders (as evidenced by, inter alia, introducing similar regulations), the authors also answer the question as to what extent the models described are implemented by national entities. An analysis of the case studies of the best foreign TTCs, and then comparing them with Polish practices can help to answer the question about which direction domestic entities should follow to best fulfil their mission.

\footnotetext{
${ }^{5}$ Understood as the relationships between the elements which coexistence and cooperation enables the creation and delivery of customer value, and consequently also value for the organization (Demil \& Lecocq, 2010).
} 
A description of the research methods is included in the first part of this article. Then attention was paid to the individual components of the business models: the legal form and methods of financing, the mission of operations, the work integration and the mechanisms of collaboration with the scientific and the commercial sector. Within these modules, the diversity of solutions is shown, illustrated by examples from foreign research units. The level of their utilization in Poland was also assessed. The summary identifies areas in which Polish TTC standards differ from the world leaders' and presents suggestions for directions for further development.

\section{Methodology of the research}

This article is part of the series of studies on the determinants of knowledge transfer in Poland, conducted in the Laboratory of Statistical Analysis and Evaluation of the National Information Processing Institute. It complements the results of a quantitative study devoted to the factors stimulating knowledge transfer in Poland (Feldy et al., 2014). The need for in-depth information about the solutions used in practice resulted in a decision to conduct qualitative analyses.

The study used case studies describing foreign entities as well as materials and data regarding the Polish TTCs, collected in 2011-2015 at the Institute. Examples from the most innovative countries in the world: the United States, Great Britain, Switzerland, Finland and Israel, were selected for the study. These include: the Office of Technology Licensing at Stanford University (OTL Stanford), the Technology Licensing Office at the Institute of Technology in Massachusetts (MIT TLO), Oxford University Innovation Ltd. at the Oxford University, Cambridge Enterprise Ltd. at the University of Cambridge, ETH Transfer at the Institute of Technology in Zurich, Innovation Services at the University of Oulu, Yissum Research Development Co. Ltd. at the Hebrew University in Jerusalem (Yissum), Yeda Research and Development Co. Ltd. at the Weizmann Institute of Science (Yeda) and the Technion Technology Transfer operating within the framework of the Technion Research and Development Foundation Ltd. (TRDF) at the Technion Institute of Technology. Data from the case studies was supplemented by carrying out a review of the literature and studying official reports of international organizations and national press articles, as well as materials provided by TTCs, including websites. 


\section{Components of TTC business models}

Technology transfer from universities to business depends on the efficiency of the entity designated by the home organisation for the implementation of commercialisation (Pazos, López, González, \& Sandiás, 2012; Tomczyńska, Knapińska, \& Rószkiewicz, 2014; Berbegal-Mirabent, RibeiroSoriano, \& Sánchez-García, 2015; Weckowska, 2015). Effectiveness is understood here as the effective achievement of the objectives set out by the university. These in turn are reflected in the business models of universities and the technology transfer centres themselves (Landry et al., 2013; Etzkowitz, 2014; Baglieri et al., 2015). The TTC mission is directly related to these purposes, and the legal form and method of financing provide their adequate structure. Other model components considered ${ }^{6}$, that is, the work integration model and the mechanisms of collaboration with the scientific and the commercial sector are tools that determine the level of achievement of the goals (see Figure 1).

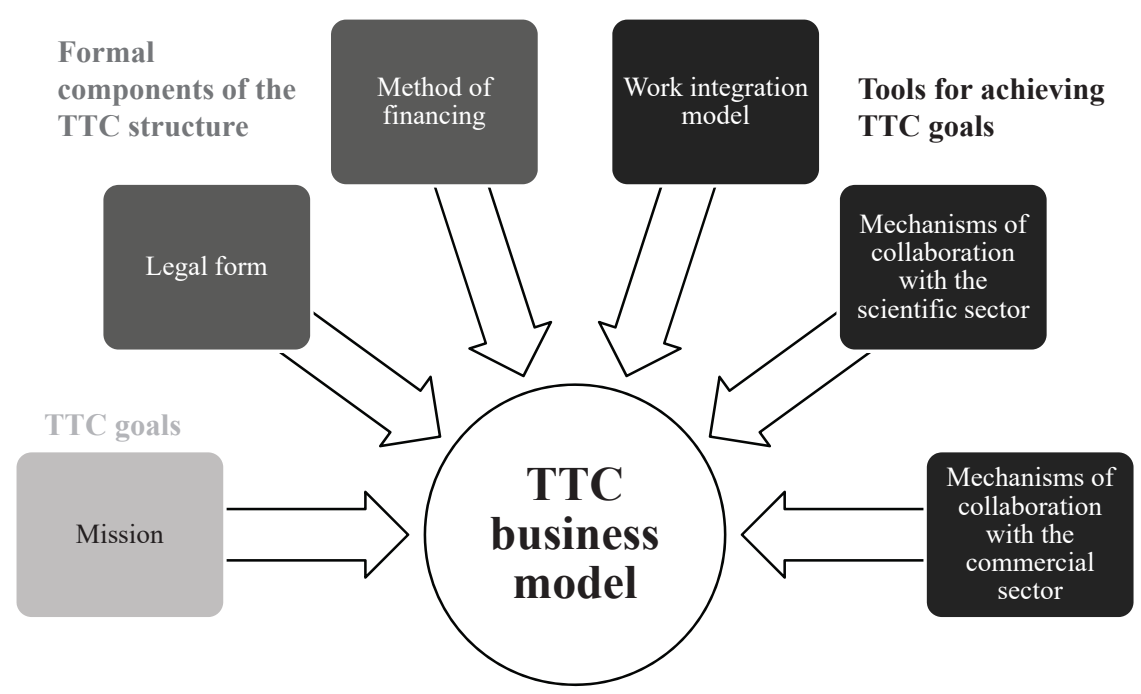

Figure 1. Components of the $\Pi \mathrm{TC}$ business models considered

Source: own development.

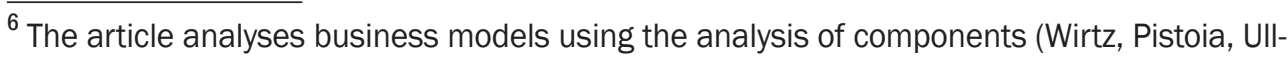
rich, \& Göttel, 2016). In practice, various components are used by authors to describe organisational models in general terms. The approach presented in this paper has been adapted to the specifics of the organisation, an academic knowledge and technology transfer centre.
} 


\section{The legal form and method of financing TC activities}

Academic technology transfer centres anchored within research units are usually subject to financing and the management structure in force at the parent unit. They are then supervised directly by the university authorities or relevant research or financial units, as it is, for example, at the ETH Transfer or OTL Stanford. Entities which operate outside the university take the non-profit or for-profit operational model, or become a foundation (Axanova, 2012). They can operate as being wholly or partly dependent on the university. Cambridge Enterprise Ltd., Oxford University Innovation ${ }^{7}$, Yissum, Yeda and Technion are entirely owned by their supervisory units, and Imperial Innovations at Imperial College in London or Hadasit at Hadassah University Hospitals in Israel are examples of companies with large groups of shareholders. Universities can also outsource commercialisation services under long-term contracts.

The level of autonomy of technology transfer centres' influences the form of financing. Apart from university funds, these entities may receive support from the national budget, apply for funding of projects and grants, as well as share in profits from the commercialisations conducted. The mechanism of income dependence on the effectiveness of TTCs is successfully used, for example, by MIT TLO and OTL Stanford, charging a 15 percent commission on their activities. In the case of Oxford University Innovation, the share is 30 percent. Another model is used by the ETH Transfer which transfers any surplus (including income) from its operations to the budget of the Institute of Technology in Zurich which fully funds it.

In the literature, there is a belief that developing an optimal organisation model is an individual matter, tailored to the specific needs of universities (Schön et al., 2013). The business approach is closer to the scientists who want to commercialise their inventions, as well as recipients of new technologies from the private sector (Hockaday, 2009). The popularity of establishing commercial companies stems from the striving of TTCs for independence and a sense that this form will operate more efficiently than a unit attached to a larger institution. It should be noted that the used legal forms and financing mechanisms in practice depend primarily on domestic regulations.

\footnotetext{
${ }^{7}$ The company, however, has a separate Isis Enterprise advisory department, also dedicated to researchers from outside the university which, on a commercial basis, provides expert services in all aspects of technology transfer, acting also as an investor - in exchange for a share in the profits, it assumes some of the risk of investing in new technologies.
} 
In Poland, the legal form of technology transfer centres is governed by Article 86 of the Law on Higher Education of 27 July 2005 (Journal of Laws No. 164, item 1365) which states that this type of innovation centre operates as a university unit on the basis of regulations approved by the senate or in the form of a commercial company or a foundation on the basis of relevant documents. The formula of a university company is to protect the university against risks arising from direct involvement in a project in force of market laws. According to Bąkowski (2015), the most popular form of activity is a TTC within the structure of research institutions. In 2014, up to $83.3 \%$ of centres operated within their parent units, with companies accounting for $9.6 \%$, and $7.1 \%$ foundations.

\section{The TTC mission}

Placing TTCs within parent units result in the centres' limited autonomy in defining the purpose of their operations. Their mission is determined by the size of the university, its administrative structure and budget. Moreover, the activities of the centre are influenced by the local environment, the subjective goals of potential stakeholders, and the availability of investment funds. In defining the mission, the TTC determines the range of services provided for the parent unit and gives priority to the dimensions of the activity, such as influencing the economy, generating profits from commercialisation and compliance with legal regulations and the state policy in the field of technology transfer. The traditional approach to the definition of TTC involves simultaneous reference to all of these areas, but later studies (Sharer \& Faley, 2005; Weeks, 2006) indicate a practice to prioritise the main goals of the centre.

Axanova (2012) identifies three business models according to their mission. The model focused on supporting the parent university within the distribution of knowledge is called a service model. This feature can be attributed to the ETH Transfer which closely cooperates with scientists obliged by the university to disclose inventions and collaborate with the TTC. Similarly, Cambridge Enterprise Ltd. focuses on providing services to their alma mater researchers. The methods used are to generate the greatest benefit to the University of Cambridge and its researchers - achievements are rewarded in order to give motivation to take on new challenges. The core of the relationship with the science sector and the business sector is, however, the commercial view of all the relationships. 
The business model which strongly emphasises the benefits for the local ecosystem is called by Axanova the economic development model. The social dimension of the technology commercialisation process is highlighted, for example, by Oxford University Innovation and OTL Stanford. In these centres, the essence of the whole process of knowledge and technology transfer is the social value generated by research results. Centres showing the characteristics of the economic development model support solutions which can contribute to the creation of start-ups or those that correspond to the needs of the local community. As a rule, they cooperate closely with the authorities in the region, as well as operate within larger initiatives, such as technology parks.

The third model - the revenue model, focused on revenue-generating opportunities is more natural to the units operating outside the university and self-managing budgets. A survey of American scientists showed that private academic TTCs are more likely to generate profit from commercialisation (Abrams, Leung, \& Stevens, 2009). An example of success in this field is the MIT TLO, operating on behalf of a non-public university what influences the fact that all its activities related to technology transfer must be based on economic calculations.

Centres in Poland most frequently use the service model. According to Bąkowski (2015), their activity is addressed mainly to scientists, and external goals, such as entrepreneurship and local or international collaboration, are rarely mentioned among the priorities. This conclusion is also consistent with the structure of the recipients of domestic TTC services, dominated by representatives of the scientific community. As much as on the websites of centres, references to the impact on the local community and economy can be found, in practice, the centres focus primarily on the beneficial impact on the environment of the university (Kijeńska-Dąbrowska \& Lipiec, 2012). There are exceptions - the features of the economic development model can be found at the Center for Technology Transfer and Entrepreneurship at the Warsaw University of Technology. This is evidenced by it being based in the Centre for Innovation and Technology Transfer the activities of which are to assist not only scientists affiliated with the University, but any coming from Mazovia. The stated primary goal is to create a regional ecosystem in which joint projects are carried out, and their results are transferred to the economy. In turn, the Centre of Technology Transfer of the Wrocław Technical University is funding its activities itself. This approach, close to the revenuebased model, is, however, the least compatible with the characteristics of Polish entities. In Poland, the most important sources of TTC funding are grants and projects (on average $47 \%$ of the budget) and funding from the 
parent university (45\%). Revenue from their own activities accounts for only $8 \%$ of the budget, but most of the Polish centres do not have any revenue from this source (Bąkowski, 2015).

Taking into account the considered components of business models, we can assume that TTCs in Poland are a homogeneous group of entities, largely dependent on higher education institutions and their funding.

\section{TC work integration model}

Great importance in the handling of commercialisation processes is attributed to qualified staff. Their efficient cooperation with the creators of inventions determines the productivity of technology transfer centres (Weckowska, 2015). Studies have shown that a more important factor than the size are the qualifications of the team of workers (Campbell, 2007). The efficiency of services within the TTCs requires expertise in the area of science and business (Landry et al., 2013). Scientific expertise is necessary in contact with scientists. On the other hand, knowledge of business processes is useful in establishing a partnership with entrepreneurs and investors (Axanova, 2012; Baglieri et al., 2015; O'Kane, Mangematin, Geoghegan, \& Fitzgerald, 2015). What is more, different skills should define the employees recognizing the possibility of commercialisation (knowledge of technology, knowledge of the scientific field), employees evaluating the technical aspect of inventions (testing, prototyping) and those taking responsibility for the final phase of commercialisation (searching for funding, negotiating contracts, verifying the customer market). Answering the demand for different skills, some services are outsourced (e.g. legal advice) or diversification of employment at different stages of operations takes place (Campbell, 2007; Landry et al., 2013).

Axanova (2012) identifies three models of work integration: horizontal, vertical and hybrid. The horizontal model takes into account team workflow division according to specific tasks. The team consists of specialists with diverse skills and performing different functions in the process of commercialisation. Such a solution is typically used by technology transfer units operating at larger universities. In practice, the vertical model of work integration is more common, where individual employees watch over the entire process of commercialising the invention assigned to them. The advantage of this solution is the possibility of strengthening the relationship between scientists and TTC experts. What is more, the TTC team gains experience at each stage of the commercialisation process (Wheaton, 2006). However, at the 
outset, its members are required to have extensive knowledge. The vertical division of workflow is successfully used by Cambridge Enterprise Ltd. The centre employs the so-called enterprise champions - scientists who are also entrepreneurs and agents of the commercialization of knowledge.

Foreign experience shows that the model of work integration of a team involved in technology transfer from universities to the economy usually takes the form of the hybrid model, which - regardless of the vertical or horizontal work integration - also takes into account the field of specialization (Axanova, 2012). An example of such an approach is the activity of the OTL Stanford and Israeli TRDF. The California university pays special attention to the adequate technical knowledge of the field and skills in marketing and social contacts of the person responsible for the commercialisation of specific invention. The Technion Institute of Haifa employs innovation brokers who are specialists in crucial research domains. The segregation of duties by technology field is also used in the Swiss ETH, in which commercialisation is dealt with by researchers from such fields as chemistry, biochemistry, physiology, electrical engineering and biology who at the same time have experience of working in R\&D centres of global companies.

In Poland, the vertical model of work integration is used by the Centre for Technology Transfer CITTRU at the Jagiellonian University. It employs six innovation brokers, responsible for serving academic staff of the university. Experts at CITTRU take care of managing the intellectual property and the commercialisation of research results, as well as they aim to improve university cooperation with business and support scientist in research commissioned by private contractors. The Technical University Centre for Technology Transfer University of Lodz Sp. z o. o. [Ltd.] employs specialists with skills in many areas, enabling comprehensive support of the path to commercialization. Their work focuses primarily on supporting the licensing and the sale of the rights to scientific results. Another model of work integration was implemented by the centre at the AGH University of Science and Technology. The horizontal model stems from the structure of the unit which consists of three independent divisions: technology transfer, collaboration with the economy and the protection of intellectual property. A similar structure has been applied by the Innovation and Technology Transfer Centre (CITT) at the Silesian University of Technology.

From the point of view of the efficient operation of the centres in Poland, the matter of stabilizing the number of staff and developing their skills seems to be more important than introducing a specific work integration model. Domestic TTCs face insufficient human potential (Niedzielski \& Łobacz, 2012), 
what is manifested by a relatively low employment and the lack of sufficient competences (Matusiak \& Guliński, 2010). One of the reasons for this is the method of financing the activities of the units, that is, its dependence on implementing external projects. This results in the fact that people are employed to handle projects and not to act strictly for commercialization. In addition, financial conditions of Polish TTCs often do not allow the acquisition of qualified staff with commercial experience; this factor negatively affects the results of commercialisation.

\section{Mechanisms of cooperation with the science sector}

The organizational culture of a university and its designed priorities determine the perception of a scientist and his work in the context of knowledge and technology transfer (O'Shea, Allen, Chevalier, \& Roche, 2005). There are two approaches. In the approach called traditional in this article, a scientist conducts research, and TTC staff examines whether the results of his work have any commercialisation potential. It is the TTC to be responsible for the final launch of the invention onto the market. The second view, which can be defined as a novel one, tells us to perceive a scientist not only as a researcher, but also, to a certain extent, an entrepreneur who commercialises inventions, for example by setting up a spin-off company. The perception of the role of a scientist in knowledge transfer as a traditional or a novel one depends on many factors: the historical background, the university's strategy, the type of research etc.

Active participation of inventors in the whole process of commercialisation is considered to be a prerequisite for success in the MIT TLO; a study conducted by the Massachusetts Institute of Technology showed that 70\% of licensees were already known to inventors. At the ETH Zurich, the basic form of technology transfer is licensing intellectual property and encouraging employees to create spin-offs licensed by the higher education institution. A researcher or a team of researchers who want to develop a product and undertake economic activity have priority to obtain a license; such a decision is very often taken. Encouraging scientists to commercialise is also at the core of the OTL Stanford success - the model introduced in the 1980s, taking into account, inter alia, an incentive system for commercializing researchers, proved to be so effective that in the first year it generated income ten times greater than in the preceding 15 years. 
A different model defines scientific units in Israel. The most significant TTCs: Yissum, Yeda and TRDF, operate according to a similar scheme which starts with the discovery of an idea and proposing an action plan to its developers. The rule of professionalization applies - scientists are expected to mainly conduct research, and not to be entrepreneurs. The process of commercialisation should be left to professionals who regularly participate in academic seminars and maintain a network of contacts in laboratories. Maximum one day a week should be spent by academics on business consultancy.

There are various forms of the manner of encouraging scientists to participate in the process of technology transfer. At the ETH Transfer, the obligation to notify in writing about each invention, any result of research and development work which has the characteristics of an innovation as well as about any computer program is imposed on scientists. The expectation that developers will notify the technology transfer centre of the inventive activities being undertaken should be considered typical of countries with legislation based on university inventions' property, but there are also less formal solutions. For example, the Oxford University emphasizes freedom of choice of the researchers and the fact that they can carry out any kind of research without trying to commercialise them. The Oxford University Innovation offers assistance in the commercialisation of knowledge, but directs it only to those willing, without exerting pressure on researchers ${ }^{8}$. The prevailing view is that accelerating research and the creation of high-tech inventions are more likely when working in large, interdisciplinary teams, therefore Oxford University Innovation primarily helps scientists to establish contacts with representatives of different sectors and domains.

According to Baglieri, Baldi and Tucci (2015), one of the dimensions of the academic TTCs' activity is the more or less selective directing of services to scientists. In the first case, the centre focuses on scientists with the greatest achievements, also in terms of collaboration with business (the socalled principal investigators: Casati \& Genet, 2014; Mangematin, O'Reilly \& Cunningham, 2012; Boehm \& Hogan, 2014). The less selective directing means including all researchers in the activities. This mechanism is used, for

\footnotetext{
${ }^{8}$ The British university motivates scientists to entrepreneurship with attractive profit-sharing rules. The researchers share of revenues from licensing depends on their amounts involved. In the case of the lowest revenue, the percentage rises to $60 \%$, which leads to engaging in commercialisation regardless of the expected global revenue from the project. In the case of creating a spin-off company, the creators receive shares of a similar amount to the university, and their percentage of the revenues from consulting services can reach $85 \%$.
} 
example, by the Zurich Technical University which wants to see involvement in the transfer of knowledge as the essence of academics' activities - apart from research. A different strategy was adopted by the Oxford University in the belief that commercialisation should relate only to some scientists, and the best of them will find their way to the TTCs. Both of these described practices are, however, far from the tactics described by Axanova (2012), which consists of protecting all inventions produced in the research institution with patents (protect-it-all). Such an approach is characteristic of the university whose primary objective is to provide services for their own academic staff. It brings inventors' satisfaction, but is associated with the risk of spending money on patents that are unlikely to generate income. Both the ETH, and Oxford use the business-like model version, making decisions about protection taking into account the type of technology risk, market potential of the product, etc.

Polish regulations assume the obligation of universities to approve regulations setting out the rules and procedures for commercialisation of the results of research and development (Krzewiński et al., 2014). The regulations are full of provisions devoted to TTC tasks such as consultancy and promotion of entrepreneurship. They specify the responsibilities of researchers (the Gdansk University of Technology: „a developer of an inventive project, an innovative solution, a computer program or a database is required to immediately report the fact of the creation as a result of intellectual work" and "to cooperate in the process of commercialisation": the Gdansk University of Technology, 2015, pp. 6-7) and the rules for the distribution of profits from the commercialisation (the University of Warmia and Mazury in Olsztyn: 50\% of the profit shall be the creator's share, $20 \%$ belong to the unit employing him or her and to the university, and $10 \%$ is received by the Centre for Innovation and Technology Transfer: UWM, 2011). Too rarely, however, activities of technology transfer centres aimed at the scientific community go beyond the traditional advice and training. The exception here is the BioTech International Institute of Molecular and Cell Biology in Warsaw which finances scholarships for doctoral students carrying out application research projects and finances internships for researchers in innovative companies.

\section{Mechanisms of cooperation with the commercial sector}

Technology transfer centres are usually perceived as intermediaries between researchers and companies (cf. Baglieri et al., 2015; O'Kane et al., 
2015; Siegel \& Wright, 2015). Thus, they face the need for creating value for various groups of stakeholders (Landry et al., 2013), with different goals and needs, and thus divergent expectations of TTCs.

Shaping multiple identities and balancing the academic, commercial and social dimensions of the image created by the TTC is one way to manage conflicts arising from the existence of groups of stakeholders with different expectations and organization cultures. Such an action does not lack drawbacks, because it can cause blurring of the identity and image of the TTC. Therefore, the key factor for success is implementing a decentralized management style that preserves the sensitivity of relations with stakeholders and allows to flexibly respond to their needs (Debackere \& Veugelers, 2005).

TTCs capable of understanding the motives of all parties are successful within technology transfer (Ankrah, Burgess, Grimshaw, \& Shaw, 2013). This points to the practice of relationship-oriented commercialisation (Weckows$k a, 2015)$. The importance of building extensive networks of contacts as well as close and long-term relationships within networks which should be managed at every stage of technology transfer, is growing. This approach undermines the legitimacy of attributing considerable importance to the transactional aspects of research commercialisation (cf. Perkmann \& Walsh, 2007; Alexander \& Martin, 2013).

Transfer centres take at least a few decisions regarding establishing partnerships with the commercial sector, namely: with whom, at what stage and what tools will be used to establish contact. A TTC conducting the practice of transaction-oriented commercialisation perceives entities from the private sector as potential buyers. They take up one-way marketing activities, oriented at the result of negotiating agreements aimed at sales or licensing. In seeking commercial partners they rely on the contacts of scientists and assume the "first come first served" approach.

More effective in establishing lasting relationships are those centres in which relationship-oriented commercialization dominates. Contacts with potential investors and licensees must be established at an early stage of the research, for there to be an opportunity to engage in joint projects. The activities are aimed at building partnerships in order to maximize the opportunities for research cooperation; therefore negotiations are conducted with many entities, not only from the scientific circle. An example is the OTL Stanford, focused on building strong and long term relationships with the commercial sector. When promoting new inventions, employees interact primarily with companies with which they have already worked. Similarly, Innovation Services at the University of Oulu is trying to gather extensive knowledge 
about possible industrial partners and the specifics of their activities. To learn business processes, TTC specialists pay visits to the premises of companies and discuss the potential benefits of technology transfer together with their representatives. In Israel, centres organize mixed seminars, during which the possibilities and expectations of business representatives are probed. These measures guide scientific research into the areas of practical applications.

A wide range of services in supporting business partners in establishing contacts with university research teams is offered by the ETH Transfer. Having received a demand from an enterprise, the centre provides an analysis of the competence of the experts at the University of Technology, organises the exchange of personnel and arranges the conduct of joint projects co-financed by the government. Study visits to the ETH laboratories and workshops with companies are also organized; their goal is to develop proposals for innovative fields of cooperation.

A unique and extremely effective communication tool is still to be found at the Oxford Innovation Society (OIS), managed by Oxford University Innovation. The OIS brings together scientists, investors, university spin-out companies, specialists in technology transfer, local entrepreneurs and innovative international corporations. The forum members regularly receive a newsletter and information about patent applications managed by the Oxford University Innovation. In addition, they are invited to tailor-made seminars and meetings. An interesting form of this are dinners organized three times a year - with lectures and a reception, when the participants make contacts, exchange experiences, get to know what the scientists are offering and what are the needs of the commercial sector.

Compared with their Western counterparts, TTCs in Poland are relatively inexperienced in the process of knowledge commercialisation. In order to change this situation actions aimed at promoting the development of relations between the academic sector and industry are required. The activities of domestic centres are directed out to local stakeholders, mainly scientists themselves and includes entrepreneurs to a rather small extent. Krakow CITTRU is an example of conducting an intensive and wide-ranging communication with companies from Poland and other countries in Europe, Asia and the USA. In 2015, the centre supported the work of brokers who held direct meetings with business representatives, by running the sciencemarket.pl website. The website presented the products of university research, including inventions designed for implementation, to the commercial sector (the Jagiellonian University, 2015). 
Taking up initiatives in line with international trends is also sought by the Wroclaw Centre of Technology Transfer of the Wroclaw Technical University. As a member of the Enterprise Europe Network appointed by the European Commission, the TTC actively supports the development of entrepreneurship in western Poland. As part of this activity, it offers small and medium-sized enterprises free and comprehensive information, consultancy and training services in the field of technology transfer and support activities in the international market. It also organizes meetings, seminars and thematic conferences, as well as publishes a bulletin "High-Tech" and regularly collaborates with the media (Firlej \& Kamińska, 2012).

\section{Conclusions. Towards international standards}

In order to develop the most effective technology transfer practices, adapted to the dynamically changing academic and business sectors, technology transfer centres continue to evolve and develop increasingly complex strategies. Experience of prestigious TTCs shows that it is difficult to identify the single most effective business model for commercialisation processes. This depends on the size of the parent unit and its administrative structures, method of financing, its formulated mission and the underlying commercialisation mechanisms.

Specific solutions used by selected TTCs can be implemented by other centres, if they are at a similar stage of development (Pazos et al., 2012). It should not be expected that the transfer of foreign good practice onto the domestic market will be complete. In Poland, the tradition of collaboration between science and industry is much shorter, and the cooperation of universities and enterprises has not yet reached maturity. Domestic TTCs undergoing the process of development and the evolution of their business models, cannot, however, underestimate the mechanisms developed in foreign centres and the changes ongoing in them. A critical look at the activities of Polish TTCs seems to be an important element of the discussion about the efficient transformation of traditional universities into entrepreneurial universities.

In Poland, the TTCs operating within supervisory research units are a sizeable and homogenous group, when considering the models of operations, which manifest features of the service model. The popularity of this model is the result of Polish TTCs taking up safe positions at universities, where their position and funding do not depend on their performance indicators. 
Inclusion of the revenue model in the mission of Polish TTCs and practical implementation of its characteristic elements could result in more centres than before achieving commercialization effects, rather than only conducting advisory and training activities.

The stimulation of technology transfer processes is not possible without increasing the intensity of contacts with the commercial sector. Currently, the structure of the recipients of Polish TTC services is dominated by scientists and other university employees, while only $17 \%$ are owners and managers of small and medium-sized companies (Bąkowski, 2015). Such an inside-out business model (Landry et al., 2013) is rather a commitment to solving the problems of the research community (e.g. legal issues, access to capital) than directing services to entrepreneurs. Perhaps this model makes transfer centres more "bottlenecks" than "facilitators" in the spread of innovation (Litan, Mitchell, \& Reedy, 2008, pp. 31-57). For this reason, it is necessary to develop business models oriented to the outside, which will enable the establishment of strong ties with enterprises, identification of their needs and the preparation of tailor-made solutions. This approach should be a counterbalance to the focus on scientists as a key resource in developing products for industry. Becoming a full-fledged entrepreneurial university that stands out in conducting communication between the academia, business and social sectors, requires implementation of relationship-oriented commercialisation practices by the TTC.

At the best universities (e.g. in Oxford), researchers themselves acknowledge business success as a component of academic prestige. In Poland, cooperation with the commercial sector usually slows down the development of research careers. Perceiving commercialisation as a necessary component of the development of entrepreneurship and innovation should be reflected both in the established policy of promotional and incentive programmes for departments and individual academics and students. If publishing research results in international journals with a high impact factor is still by far the more important for the career development of researchers, scientist are reluctant to devote time and effort to commercialisation.

The transformation of technology transfer from peripheral activities into central activities and the greater involvement of researchers in the commercialisation of their inventions also require the institutions employing them to secure funds to cover the costs of patenting and negotiating licensing agreements, as well as providing support in the form of professional TTC staff. Undoubtedly, the change in the structure of employment that has occurred in Poland in the last ten years is a positive development. There has been an 
increase in the number of full-time professional staff, and the number of those operating as advisers, consultants or lecturers on the basis of commission contracts has decreased (Bąkowski, 2015). Transfer centres, however, still point to the need for staff to acquire new competences so that their experts can independently assess potential commercialisation scenarios and prepare appropriate strategies for technology sales. In practice, the number of TTC employees is usually small, and their work is mainly focused on the protection of intellectual property rights for higher education institutions and do not include the knowledge of issues in the area of entrepreneurship. These deficiencies are compensated by delegating certain tasks to outside consultancy (Bąkowski, 2015). Such actions are not conducive to building lasting relationships with stakeholders, which is why staff training for business skills and attracting employees with experience in the commercial sector seem necessary.

Apart from that, the weakness of technology transfer in Poland is also associated with the applicable rules of the assessment of scientific units'. It is not about "fetishizing" commercialisation activities, as then patents are treated - as in the current parametric assessment - as a source of points to win, and not as factual assets of the commercial (Niedzielski \& Łobacz, 2012). Most often, it is said that however obtaining patents is rewarded in the Polish system, it does not contribute to increasing deployments at universities. The patent process is laborious and expensive, and in the case of innovation, time is what matters. Knowledge transfer can be included in the assessment process in a more subtle manner - for example, the British system of Research Excellence Framework includes the impact on the social and economic life of the country within the criteria of the scientific excellence of universities (20\% of the final assessment).

Even the greatest efforts of TTCs to perform their assigned tasks will not contribute to achieving spectacular results if no favourable conditions are met, such as a high enough university spending on R\&D, the scientific excellence of the conducted research, which results in vital discoveries, the maturity of the TTC resulting from a sufficiently long period of activities and the TTC's favourable location. The examples cited in the article show that, despite the fact that the general condition of domestic TTCs is not fully satisfactory, there are, however, centres that successfully follow the trends set up by the foreign TTCs which have mastered their skills in the field of technology transfer and knowledge commercialisation. 


\section{References}

Abrams I., Leung, G., \& Stevens A. J. (2009). How are U.S. technology transfer offices tasked and motivated - Is it all about the money?. Research Management Review, Vol. 17, No. 1, 1-34.

Alexander A. T., \& Martin D. P. (2013). Intermediaries for open innovation: A competence-based comparison of knowledge transfer offices practices. Technological Forecasting Social Change, Vol. 80, 38-49.

Ankrah S. N., Burgess T. F., Grimshaw P., \& Shaw, N. E. (2013). Asking both university and industry actors about their engagement in knowledge transfer: What single-group studies of motives omit. Technovation, Vol. 33, 50-65.

Axanova L. (2012). US Academic Technology Transfer Models: Traditional, Experimental and Hypothetical. Les Nouvelles, No. 2, 125-137..

Baglieri D., Baldi F., \& Tucci, C. (2015). University technology transfer office business models: One size does not fit all. Presented at DRUID Society Conference 2015.

Bąkowski A., \& Mażewska M. (2015). Ośrodki innowacji i przedsiębiorczości w Polsce. Raport 2014. Poznań-Warszawa: SoOliP.

Berbegal-Mirabent J., Ribeiro-Soriano D. E., \& Sánchez-García J. L. (2015). Can a magic recipe foster university spin-off creation. Journal of Business Research, Vol. 68, 2272-2278.

Boehm, D. N., \& Hogan, T. (2014). A Jack of all trades': The role of PIs in the establishment and management of collaborative networks in scientific knowledge commercialisation. The Journal of Technology Transfer, Vol. 39, 134-149.

Campbell A. F. (2007). How to set up a technology transfer office: Experiences from Europe. [In:] Krattiger A., Mahoney R. T., Nelsen L., Thomson J. A., Bennett A. B., Satyanarayana K., Graff G. D., Fernandez C., Kowalski S. P., Intellectual property management in health and agricultural innovation: $A$ handbook of best practices (pp. 559-566). Oxford - Davis: MIHR - PIPRA

Casati A., \& Genet C. (2014). Principal Investigators as Scientific Entrepreneurs. The Journal of Technology Transfer, Vol. 39, No. 1, 11-32.

Carlsson B., \& Fridh A.-Ch. (2003). Technology transfer in United States universities: A survey and statistical analysis. [In:] Metcalfe J.S., Cantner U. (ed.), Change, transformation and development (pp. 379-412). Berlin - Heidelberg: Springer-Verlag.

Conti A., \& Gaule P. (2011). Is the US outperforming Europe in university technology licensing? A new perspective on the European Paradox. Research Policy, Vol. 40, No. $1,123-135$. 
Debackere K., \& Veugelers R. (2005). The role of academic technology transfer organizations in improving industry science links. Research Policy, Vol. 34, 321-342.

Demil B., \& Lecocq X. (2010). Business model evolution: In search of dynamic consistency, Long Range Planning, Vol. 43, 227.

Etzkowitz H. (2003). Innovation in innovation: The triple helix of university - industry - government relations. Social Science Information, Vol. 42, 293-337.

Etzkowitz H. (2014). The second academic revolution: The rise of the entrepreneurial university and impetuses to firm foundation, [In:] Allen T. J., O'Shea R., Building technology transfer within research universities: An entrepreneurial approach. Cambridge: Cambridge University Press.

Etzkowitz H., \& Leydesdorff L. (1995). The triple helix. University - industry - government relations: A laboratory for knowledge-based economic development. EASST Review, Vol. 14.

Feldy M., Knapińska A., Ostaszewski, M., Rószkiewicz, M.M., Tomczyńska, A., \& Warzybok, B. (2014), Naukowiec w relacjach z biznesem. Uwarunkowania transferu wiedzy w Polsce. Warszawa: OPI PIB.

Firlej J., \& Kamińska M. (2012). Wrocławskie Centrum Transferu Technologii przy Politechnice Wrocławskiej - studium przypadku [manuscript]. Poznań: CoWinners sp. z 0.0 dla OPI PIB.

Gdansk University of Technology (2015). Senate resolution no. 258/XXIII/2015 of 18 March 2015 on changes to the rules of management and commercialisation of intellectual property.

Hockaday T.(2009). What is the beststructureforan university technologytransferoffice? Retrieved April 25, 2016 from http://www.sciencebusiness.net/news/69022/ What-is-the-best-structure-for-a-universitys-technology-transfer-office

Kijeńska-Dąbrowska I., \& Lipiec K. (ed.), (2012). Rola akademickich ośrodków innowacji w transferze technologii. Warszawa: OPI PIB.

Krzewiński Z., Budasz K., Krzewińska D., Gabriel P., \& Sypniewska M. (2014). Organizacja komercjalizacji wyników badań. Warszawa: OPI PIB.

Krzewiński Z., \& Miądowicz M. (2012). Office of Technology Licensing Stanford University - studium przypadku [manuscript]. Poznań: CoWinners sp. z o.o dla OPI PIB.

Krzewiński Z., \& Pucher J. (2012). ETH Transfer przy Politechnice Federalnej w Zurychu - studium przypadku [manuscript]. Poznań: CoWinners sp. z o.o dla OPI PIB.

Krzewiński Z., \& Utrecht R. (2012). ISIS Innovation Ltd. - studium przypadku [manuscript]. Poznań: CoWinners sp. z o.o dla OPI PIB. 
Kwiek M. (2015). Uniwersytet $w$ dobie przemian: Instytucje i kadra akademicka w warunkach rosnącej konkurencji. Warszawa: PWN.

Landry R., Amara N., Cloutier J.-S., \& Halilem N. (2013). Technology transfer organizations: Services and business models. Technovation, Vol. 33, No. 12, 431-449.

Litan R. E., Mitchell L., \& Reedy E. J. (2008). Commercializing university innovations: Alternative approaches. [In:] Jaffe A. B., Stern J. L., Innovation policy and the economy. Chicago: University of Chicago Press.

Matusiak K. B., \& Guliński J. (ed.) (2010). Rekomendacje zmian w polskim systemie transferu technologii i komercjalizacji wiedzy. Warszawa: PARP.

Mangematin V., O'Reilly P., \& Cunningham J. (2012). Pls as boundary spanners, science and market shapers. The Journal of Technology Transfer, Vol. 39, No. 1, 1-10.

Marszalec J. (2012). Studia przypadków instytucjonalnego wsparcia transferu wiedzy i technologii z państwowych jednostek badawczych do biznesu: Research and Innovation Services University of Oulu, VTT Ventures Ltd., Cambridge Enterprose Ltd. [manuscript]. Warszawa: Innovatech Consulting dla OPI PIB.

Mowery D., Nelson R., Sampat B., \& Ziedonis A. (2015). Ivory tower and ind ustrial innovation: University-industry technology transfer before and after the Bayh-Dole Act. Stanford: Stanford University Press.

Niedzielski P., \& Łobacz K. (2012). Diagnoza i analiza problemów komercjalizacji wiedzy i transferu technologii na uczelni wyższej pod kątem barier natury organizacyjnej. Szczecin.

O'Kane C., Mangematin V., Geoghegan W., \& Fitzgerald C. (2015). University technology transfer offices: The search for identity to build legitimacy. Research Policy, Vol. 44, 421-437.

O'Shea R. P., Allen T. J., Chevalier A., \& Roche F. (2005). Entrepreneurial orientation, technology transfer and spin-off performance of U.S. universities. Research Policy, Vol. 34, No. 7, 994-1009.

Pazos D. R., López S. F., González L. O., \& Sandiás A. R. (2012). A resource-based view of university spin-off activity: New evidence from the Spanish case. Revista Europea de Dirección y Economía de la Empresa, Vol. 21, 255-265.

Perkmann M., \& Walsh K. (2007). University-industry relationships and open innovation: Towards a research agenda. International Journal of Management Reviews, Vol. 9, No. 4, 259-280.

Rabczenko A. (2012). Transfer technologii w Izraelu. Rola Ośrodków Transferu Technologii w sukcesie gospodarczym - studium przypadku dla Ośrodka Przetwarzania Informacji - Instytutu Badawczego [manuscript]. 
Siegel D. S., \& Wright M. (2015). University technology transfer offices, licensing, and start-ups. [In:] Link A. N., Siegel D. S., \& Wright M. (ed.). The Chicago handbook of university technology transfer and academic entrepreneurship (pp. 1-40). Chicago - London: The University of Chicago Press.

Sharer M., \& Faley T. L. (2008). The strategic management of the technology transfer function - Aligning goals with strategies, objectives and tactics. Les Nouvelles, Vol. 43, No. 3, 170-179.

Thursby J. G., \& Kemp S. (2002). Growth and productive efficiency of university intellectual property licensing. Research Policy, Vol. 31, 109-124.

Thursby J. G., \& Thursby M. C. (2002). Who is selling the ivory tower? Sources of growth in university licensing. Management Science, Vol. 48, 90-104.

Tomczyńska A., Knapińska A., \& Rószkiewicz M.M. (2014). Stosowanie nowoczesnych mechanizmów transferu wiedzy. [w:] Naukowiec $w$ relacjach z biznesem. Uwarunkowania transferu wiedzy w Polsce. (pp. 105-130). Warszawa: OPI PIB.

Uniwersytet Jagielloński (2015). Raport CTT CITTRU 2015. Kraków: UJ.

Uniwersytet Warmińsko-Mazurski w Olsztynie. (2011). Przewodnik dotyczący zarządzania własnością intelektualną i ochrony prawnej dóbr niematerialnych powstałych w Uniwersytecie Warmińsko-Mazurskim w Olsztynie. Olsztyn: UWM.

The Act of 27 July 2005, Law on Higher Education, as amended: Journal of Laws No. 164, item 1365.

Weckowska D. M. (2015). Learning in university technology transfer offices: Transactions-focused and relations-focused approaches to commercialization of academic research. Technovation, Vol. 41-42, 62-74.

Weeks P. (2006). Strategies for managing internal and external constituencies. AUTM Technology Transfer Practice Manual, 3rd Edition, 2(1).

Wheaton B. (2006). Managing a medium-sized technology transfer office. AUTM Technology Transfer Practice Manual, 3rd Edition, 2(1).

Wirtz B. W., Pistoia A., Ullrich S., \& Göttel, V. (2016). Business models: Origin, development and future research perspectives. Long Range Planning, Vol. 49, No. 1, 36-54.

Zuniga P. (2011). The state of patenting at research institutions in developing countries: Policy approaches and practices, No. 4. Geneva: WIPO. 